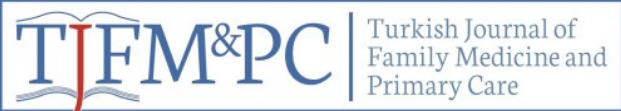

Original Research / Özgün Araştırma

\title{
The Effect of Health Expenditures on Chronic Disease Care of Chronic Patients in Hatay
}

\author{
Hatay İlinde Kronik Hastalı̆̆ 1 Bulunan Bireylerin Cepten \\ Yaptıkları Sağlık Harcamalarının Kronik Hastalık Bakımlarına \\ Etkisi
}

Nuran Şahin ${ }^{* 1}$, Cahit Özerl

\begin{abstract}
Aim: To evaluate the effect of healthcare expenditure of the patients who have chronic disease on chronic disease care satisfaction. Method: This cross sectional design study was conducted at four primary care clinics in Antakya, the central city of Hatay. The adult patients with a chronic disease at least for one year who visit the primary care centers from June to October 2017 were included in the study. A questionnaire including questions about the chronic disease, the healthcare they receive, and the factors that effect their healthcare expenditure were applied to the subjects. Also the subjects filled a chronic disease care evaluation scale- patient form (modified PACIC) to evaluate the healthcare they receive. $\mathrm{P}$ value $<0,05$ is considered as significant. Results: Of the 790 patients 400 $(50,6 \%)$ were female, while $390(49,4 \%)$ were male. The average age of the participants was $47,1 \pm 15,2$. Average Modified PACIC score was calculated as $3,29 \pm 0,7$. It was observed that healthcare intake was affected as the income level of the patients increased (Cramer's $\mathrm{V}=0,263 ; \mathrm{p}=0,001$ ). In patients with atherosclerotic heart disease, the chronic disease satisfaction score was found to be lower with $3.0 \pm 0.6$ compared to other diseases $(\mathrm{p}=0.005)$. There was no difference between the chronic disease care satisfaction scores according to the income level categories of the patients $(\mathrm{p}=0.853)$. Conclusion: Modified PACIC subscale scores of the patients who stated that their out-of-pocket health spending did not affect their service purchases were generally higher. In addition, it was concluded that the income level of the patients affected chronic disease care.
\end{abstract}

Key words: Health costs ,chronic disease, primary care

ÖZET

Amaç: Çalışmamızda, kronik hastalığı bulunan bireylerin sağlık harcamalarının, kronik hastalık bakım memnuniyetine etkisinin değerlendirilmesi amaçlanmıştır. Yöntem: Kesitsel tanımlayıcı tasarıma sahip bu çalışma, Haziran 2017-Ekim 2017 ayları arasında, Hatay'da (Antakya) dört aile sağlığı merkezinde yürütülmüştür. Belirlenen aile sağlığı merkezlerine başvuran 18 yaş ve üzeri, en az bir yıldır kronik hastalığı bulunan bireyler dahil edilmiştir. Kronik hastalığa sahip bireylerin; sosyodemografik özelliklerini, hastalıklarının özelliklerini, aldıkları sağlık hizmetlerini, yaptığı sağlık harcamalarını etkileyen faktörleri kapsayan bir anket uygulanmıştır. Ayrıca hastalara, aldıkları bakımı kendilerinin değerlendirmesine olanak veren Kronik Hastalık Bakımını Değerlendirme Ölçeği-Hasta formu (Modifiye PACIC) çalışma yürütücüsü tarafından uygulanmıştır. Bulgular: Anketi değerlendirmeye alınan 47,11 $\pm 15,20$ yaş ortalamasına sahip 790 katılımcının $400(\% 50,6)$ 'ü kadın, 390 (\%49,4)'si erkek hastaydı. Katılımcılarımızın, Modifiye PACIC puan ortalaması toplam ölçek için 3,29 $\pm 0,7$ olarak hesaplanmıştır. Hastaların gelir düzeyi arttıkça, sağlık hizmet alımının etkilendiği görülmüștür(Cramer's $\mathrm{V}=0,263 ; \mathrm{p}=0,001)$. Aterosklerotik kalp hastalığı olanlarda, kronik hastalık memnuniyet puan ortalaması 3,0土0,6 ile diğer hastalıklara göre daha düşük bulunmuştur $(\mathrm{p}=0,005)$. Hastaların gelir düzeyi kategorilerine göre kronik hastalık bakım memnuniyet puanları arasında fark görülmemiştir $(\mathrm{p}=0,853)$. Sonuç: Cepten yapılan sağlık harcamalarının, hizmet alımını etkilemediğini belirten hastaların Modifiye PACIC alt ölçek skorları genel olarak daha yüksek bulunmuştur. Ayrıca hastaların gelir düzeyinin kronik hastalık bakımlarını etkilediği sonucuna ulaşılmışır.

Anahtar Kelimeler: Sağlık harcamaları, kronik hastalık, birinci basamak

Received date / Geliş tarihi: 27.03.2020, Accepted date / Kabul tarihi: 05.04.2020

${ }^{1}$ Mustafa Kemal Üniversitesi Tıp Fakültesi Aile Hekimliği Anabilim Dalı. Antakya-Hatay-TÜRKIYYE.

*Address for Correspondence / Yazışma Adresi: Nuran Şahin Adıyaman Tut İlçe Devlet Hastanesi Tut/Adıyaman-TÜRKIYE.

E-mail: tek_yildiz5678@hotmail.com

Şahin N, Özer C. Hatay İlinde Kronik Hastalığı Bulunan Bireylerin Cepten Yaptıkları Sağlık Harcamalarının Kronik Hastalık Bakımlarına Etkisi.TJFMPC, 2020;14(2): 236-245.

DOI: $10.21763 /$ tjfmpc.698564 


\section{GíRiş}

Dünya Sağlık Örgütü’nün (DSÖ) tanımına göre kronik hastalıklar, uzun dönemli ve genellikle yavaş ilerleme gösteren, tıbbi girişimlerle tedavi edilemeyen, hastalığın derecesini azaltmak ve öz bakımında kișinin işlevini ve sorumluluğunu en üst düzeye çıkarmak için periyodik izlem ve destek bakım gerektiren durumlardır. ${ }^{(1)}$

Kronik hastalığ 1 bulunan bireylerin cepten yaptıkları sağlık harcamaları da kronik hastalık bakımlarını etkileyebilmektedir. Bunu değerlendirirken öncelikle cepten sağlık harcamasının tanımını yapmalıyı. Cepten yapılan sağlık harcamaları; doğrudan hastalar veya hane halkı tarafından sağlık hizmetleri için yapılan ödemelerdir. Cepten yapılan harcamanın yükü bireylerin sağlık hizmet kullanımını, özellikle pahalı hizmet kullanımını ve sağlık statüsünü etkileyebileceğinden, cepten harcama boyutunun ve alt gruplar itibarıly dağılımının iyi yapılmas1 gerekmektedir. ${ }^{(2)}$ Cepten harcamalar ilaç, hekim hizmetleri, hastaneye yatış ücreti, tıbbi malzemeler gibi sağlıkla ilgili hizmetler için yapılmaktadır. ${ }^{(3)}$ Cepten yapılan harcamalar tıbbi giderler adı altında üç ana başlıkta incelenmektedir. Tıbbi olan doğrudan giderler; hastaneye yatı̧lar, acil servis kullanımları, ayaktan tedavi giderleri. Tibbi olmayan doğrudan giderler ise; hastaneye ulaşım giderleri, hastalığın kontrolünü kolaylaştıran ürünler (örneğin, astımı olan bir hasta için antialerjik yastıklar), evlerde yapılan ana tamiratlardır. Dolaylı giderler ise: İş ve okul günü kayıpları, iş veriminde düşmeye bağlı ücret kayıplarını içermektedir. ${ }^{(4)} \mathrm{Bu}$ doğrudan ya da dolaylı giderler için yapılan ödemelerin cepten harcama tanımı gereği, cepten harcama olarak kabul edilmesi için, bu harcamanın birey veya hane halkının bir hizmet sunucuya ödeme yaptıktan sonra, ödediği miktarın bir kısmını veya tamamını başka kişi veya kurumdan geri ödeme veya yardım olarak geri almaması gerekmektedir. ${ }^{(5)}$ $\mathrm{Bu}$ durumda, cepten harcama miktarı, geri ödeme veya yardım olarak bireye veya hane halkına geri dönen miktar çıkarıldıktan sonra kalan miktardır. Sosyal Güvenlik Kurumu'na bağlı bir bireyin ilaç için ödediği paranın tamamını SGK' dan geri alması durumunda, cepten harcama yapmamış olacaktır. ${ }^{(6)}$

Kronik hastalığı olan bireylerde cepten yapılan harcamalar, birçok istenmeyen/beklenmeyen etki yaratabilir. $\mathrm{Bu}$ nedenle, özellikle yoksulların sağlık hizmetleri kullanımını engellemeyecek ve sağlık harcamaları ile ilgili finansal risklere karşı korunmalarını sağlayacak muafiyet ve/veya daha düşük cepten harcamaları öngören programlarının oluşturulması gerekir. ${ }^{(7)}$ ABD'de sağlık güvencesi kapsamında olmanın hane halklarını yüksek cepten harcama yapmaya karşı koruyamadığı, ancak, gelir seviyesi düşük hane halkları için en iyi finansal korumanın, daha kapsamlı hizmet paketi ve ilaçlar için asgari düzeyde katkı payı uygulayan kamu sağlık güvencesi programları tarafından sağlandığı belirlenmiştir. ${ }^{(8)}$ İlaç konusu ile ilgili olarak, cepten harcamalar temel ilaçlar dışındaki ilaçlar için söz konusu olduğunda olumsuz etkilerinin daha az olacağ vurgulanmaktadir. ${ }^{(9)}$

$\mathrm{Bu}$ araştırmanın amacı, kronik hastalığ bulunan bireylerde cepten yapılan sağlık harcamalarının kronik hastalık bakım memnuniyetine etkisini değerlendirmek ve etkileyen faktörleri belirlemektir.

\section{YÖNTEM}

Kesitsel tanımlayıcı tipte olan araştırma için, Mustafa Kemal Üniversitesi Klinik Araştırmalar Etik Kurulunun onayı ve Hatay İl Halk Sağlığı Müdürlüğünden izin alınmıştır. Hatay il nüfusu 1.520.967 kişi, merkez ilçe Antakya'nın nüfusu ise 347.904 olup burada yaşayan 18 yaş üstü kişi sayısı 290.560 'dır. Kronik hastalıkların Türkiye'deki sıklığını \% 35 kabul ettiğimizde $\mathrm{d}=0,04$ hatayla ve $\% 95$ güven ile hesaplandığında ulaşılması gereken hasta sayısı 550 olarak bulunmuştur. $\mathrm{Bu}$ bağlamda \% 20 oranında olası eksiklikleri düşünülerek ulaşılması gereken hasta sayısı 660 olarak belirlenmiştir

Antakya merkez ilçesinde 35 aile sağlığı merkezi (ASM) ve 86 Aile Hekimliği Birimi bulunmaktadır. Araştırma 2017 Haziran-Ekim ayları arasında Hatay İli Antakya İlçesinde Halk Sağlığı Müdürlüğünün izin verdiği Serinyol 1 ve 2, Anayazı ve Karaali Aile Sağllğı Merkezinde olmak üzere 10 Aile Hekimliği Biriminde yapılmıştır. Çalışma süresince, haftanın 2 günü aile hekimlerine başvuran 18 yaş üstü birinci basamağa başvuran en az 1 yıldır kronik hastalığ 1 bulunan 900 hasta bilgilendirilerek davet edilmiştir. Elli kişi katılmak istemediğini ifade etmiştir. Altmış anket eksik ya da tutarsız yanıtlar nedeniyle analiz dışı bırakılmıştır. Çalışmamıza, Türkçe konuşamayan, gebeler, çalışmaya katılmayı kabul etmeyen ve onam veremeyecek durumda psikolojik ve bilişsel 
rahatsızlığı olan hastalar çalışma dişı birakılmıştır.

Sosyodemografik bilgiler, sosyal güvenceleri, gelir düzeyi, yaptığı sağlık harcamaları, ilaç uyumu ve kronik hastalık bakım memnuniyetini ölçen Modifiye PACIC Ölçeği'nden oluşan 45 soruyu içeren anketler asistan ve intörn hekimler tarafından gönüllü onam formu alındıktan sonra yüz yüze görüşme yöntemi ile uygulanmıştır. Kronik bakım modelinin temel 6 öğesi doğrultusunda oluşturulan Türkçe Modifiye PACIC Ölçeği, 26 maddeden ve 5 alt boyuttan oluşmaktadır. ${ }^{(6)}$

$\mathrm{Bu}$ alt boyutlar:

1. Hasta Katılımı: Karar vermede hasta verisi ve kapsamını belirleme faaliyetlerdir.

2. Sağlık Hizmetleri Sunum Planı\Karar Verme Desteği: Hastaların bakımları hakkındaki görüşlerini artırmak için bilgi sağlama ve bakımı organize etme faaliyetleridir.

3. Amaç Belirleme\Rehberlik: Belirli, işbirlikçi amaçlar belirlemek için bilgi edinmektir.

4. Problem Çözme: Tedavi planı oluşturmada potansiyel engelleri, hastaların sosyal ve kültürel çevrelerini dikkate almaktır.

5. İzlem\Koordinasyon: Ofis temelli bakımı sağlamak, güçlendirmek, gelişmiş koordineli bakımı belirlemek için hastalarla verimli ilişkiler düzenlemektir.

Toplanan veriler, SPSS 21 paket programı kullanılarak analiz edilmiştir Kullanılan bütün istatistiksel testlerin önemlilik sınırı 0,05 olarak belirlenmiştir. Verilerin analizi için önce kayıp değerler incelenmiştir. Çalışmanın sonuçlarını önemli ölçüde değiştirebilecek gözleme rastlanmamıştır. Çalışmada belirtilen demografik özellikler için tanımlayıcı istatistikler kullanılmıştır. Verilerin analizinde Student- $t$ test ve kategorik değişkenler için ise ki-kare testleri kullanılmıştır.

\section{BULGULAR}

Çalışmaya toplam 790 hasta alınmıştır. Bu hastaların 400 (\% 50,6)'ü kadın iken, 390 (\% $49,4)$ ' 1 erkek hastayd. Ortalama yaş $47,1 \pm$ 15,2 (18-75) olarak bulunmuştur. Kadınlarda ortalama yaşı $45,5 \pm 14,6$ ve erkeklerin ortalama yaşı $48,6 \pm 15,5$ idi $(p=0,004)$. 
Tablo 1. Hastalarmn Sosyodemografik Bilgileri

\begin{tabular}{|c|c|c|c|c|}
\hline & & $\mathrm{n}$ & $\%$ & p* \\
\hline \multirow{3}{*}{$\begin{array}{l}\text { Medeni } \\
\text { Durum }\end{array}$} & Evli & 526 & 66,6 & \multirow{3}{*}{0,001} \\
\hline & Bekar & 174 & 22,0 & \\
\hline & Boşanmış & 90 & 11,4 & \\
\hline \multirow{2}{*}{$\begin{array}{l}\text { Çalışma } \\
\text { Durumu }\end{array}$} & Çalışıyor & 270 & 34,2 & \multirow{2}{*}{0,001} \\
\hline & Çalışmıyor & 520 & 65,8 & \\
\hline \multirow{7}{*}{$\begin{array}{c}\text { Meslek } \\
\text { Grupları }\end{array}$} & Öğrenci & 106 & 13,4 & \multirow{7}{*}{$\mathbf{0 , 0 0 1}$} \\
\hline & Memur & 129 & 16,3 & \\
\hline & İşçi & 85 & 10,8 & \\
\hline & Emekli & 154 & 19,5 & \\
\hline & Serbest meslek & 80 & 10,1 & \\
\hline & Ev hanımı & 216 & 27,3 & \\
\hline & Diğer & 20 & 2,5 & \\
\hline \multirow{5}{*}{$\begin{array}{l}\text { Eğitim } \\
\text { Düzeyi }\end{array}$} & Okur yazar değil & 36 & 4,6 & \multirow{5}{*}{0,001} \\
\hline & İlkokul & 203 & 25,7 & \\
\hline & Ortaokul & 117 & 14,8 & \\
\hline & Lise & 179 & 22,7 & \\
\hline & Fakülte & 255 & 32,3 & \\
\hline \multirow{5}{*}{$\begin{array}{c}\text { Sosyal } \\
\text { Güvence }\end{array}$} & Yeşilkart & 93 & 11,8 & \multirow{5}{*}{0,001} \\
\hline & Emekli Sandığ 1 & 232 & 29,4 & \\
\hline & Bağkur & 120 & 15,2 & \\
\hline & SSK & 305 & 38,6 & \\
\hline & Yok & 40 & 5,1 & \\
\hline \multirow{3}{*}{$\begin{array}{c}\text { Gelir } \\
\text { Düzeyi }\end{array}$} & 1380TL'den az & 346 & 43,8 & \multirow{3}{*}{$\mathbf{0 , 0 0 1}$} \\
\hline & $1380-4470 \mathrm{TL}$ aras1 & 381 & 48,2 & \\
\hline & 4470TL den fazla & 63 & 8,0 & \\
\hline \multirow{2}{*}{$\begin{array}{l}\text { Yerleşim } \\
\text { Durumu }\end{array}$} & Kentsel & 606 & 76,7 & \multirow[t]{2}{*}{0,001} \\
\hline & Kirsal & 184 & 23,3 & \\
\hline
\end{tabular}


Hastalarımız daha çok devlet hastanelerinden sağlık hizmeti aldıklarını ve yaklaşık \%77'sinin ilaç alımında maliyetin etkili olmadığını dile getirmiştir. "Gelir durumunuzu nasıl tanımlarsinız?" sorusuna katılımcılarımızın yaklaşı $\% 80$ 'i orta ve altında buluyorum cevabını vermekle beraber, bu durumun sağlık hizmetine ulaşmalarına negatif etkisi olduğunu ifade etmişlerdir $(\mathrm{p}=0,001)$. Ayrıca kronik hastalık sayısının sağlık hizmetine yapılan harcamalarla ilişkili olduğu, hastalık sayısı arttıkça harcamalarında arttığ 1 gözlenmiştir( $\mathrm{p}=0,007)$.
Sağlık hizmeti alımına yapılan harcamalara etki edebilecek (gelir, kronik hastalık sayısı vs.) birkaç faktörle bakım memnuniyetinin negatif etkilenmesi beklenirken, çalışma kapsamındaki hastaların kronik hastalık bakım yönetimlerinden memnuniyet puan ortalaması toplam ölçek için 3,29 $\pm 0,7$ olarak hesaplanmışıtr. $\mathrm{Bu}$ değerin de ortalamanın (PACIC ort. 2,5) üzerinde olduğu görülmüsstür. $\mathrm{Bu}$ durumun, birinci basamak sağlık hizmetlerinin ücretsiz olarak yapılmasından kaynaklandığı düşünülmektedir.

Tablo 2: Sağlık Hizmet Alımı İle Modifiye PACIC Skorunun Değerlendirilmesi

\section{Harcamalarından Dolayı Sağlık Hizmet Alımı}

\begin{tabular}{cccc} 
Alt Madde Ölçekleri & Etkilenenler & Etkilenmeyenler & p* \\
\hline Hasta Katılımı & $3,23 \pm 0,76$ & $3,33 \pm 0,81$ & 0,077 \\
$\begin{array}{c}\text { Sağlık Hizmetleri Sunum } \\
\text { Planı }\end{array}$ & $3,31 \pm 0,77$ & $3,42 \pm 0,81$ & 0,043 \\
Amaç Belirleme & $3,26 \pm 0,81$ & & 0,016 \\
Problem Çözme & $3,20 \pm 0,90$ & $3,40 \pm 0,78$ & 0,008 \\
İlem & $3,14 \pm 0,85$ & $3,37 \pm 0,85$ & 0,006 \\
Toplam Ölçek Puanı & $3,22 \pm 0,70$ & $3,31 \pm 0,84$ & 0,007
\end{tabular}

\footnotetext{
Veriler Ort. \pm SD olarak ifade edilmiştir. *Student-t testi.
}

PACIC alt ölçeklerinde sadece hasta katılımı alt başlığında fark olmadığı görülmüştür $(\mathrm{p}=0,07) . \quad \mathrm{Bu}$ durum yapılan sağlı harcamalarının sağlık hizmet alımını etkilediği gruptaki hastalar ile etkilemediği gruptaki hastaların tedavi sürecine dahil olma puanları arasındaki farkı ifade etmektedir. Sağlık bakım hizmeti almaya elverişli gelir durumuna sahip (etkilenmeyenler) hastaların aldığ 1 sağlık hizmetinin sunumundan, kronik hastalığının (hastalıklarının) takibinden ya da bu süreçte karşılaştığ 1 problemlere karşı verilen destekten ve tedavinin uygulanma adımlarından memnuniyetinin daha yüksek olduğu görülmüştür $(\mathrm{p}<0,05)$ (Tablo 2).
Çalışmaya katılan hastaların, hastalıklara göre modifiye PACIC skorları bakıldığında hipertansiyon hastaları için 3,2 $\pm 0,6$, diyabet hastaları için 3,2 $\pm 0,7$, aterosklerotik kalp hastaları için 3,0 $\pm 0,6$, kronik solunum yolu hastalığı bulunan hastaları için $3,3 \pm 0,7$, ruhsal hastalı̆̆ bulunan hastalar için ise 3,2 \pm 0,6 bulunmuştur. $\mathrm{Bu}$ kronik hastalıklar dışında

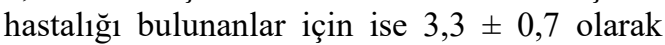
hesaplanmıştır. Modifiye PACIC alt ölçekleri ile kronik hastalıkların ilişkisine bakıldığında aterosklerotik kalp hastalığı olan hastaların kronik hastalık bakım yönetiminden memnuniyeti en düşük bulunurken, kronik solunum yolu hastalıkları ve diğer hastalıklar için ise yüksek olarak bulunmuştur (Grafik1). 


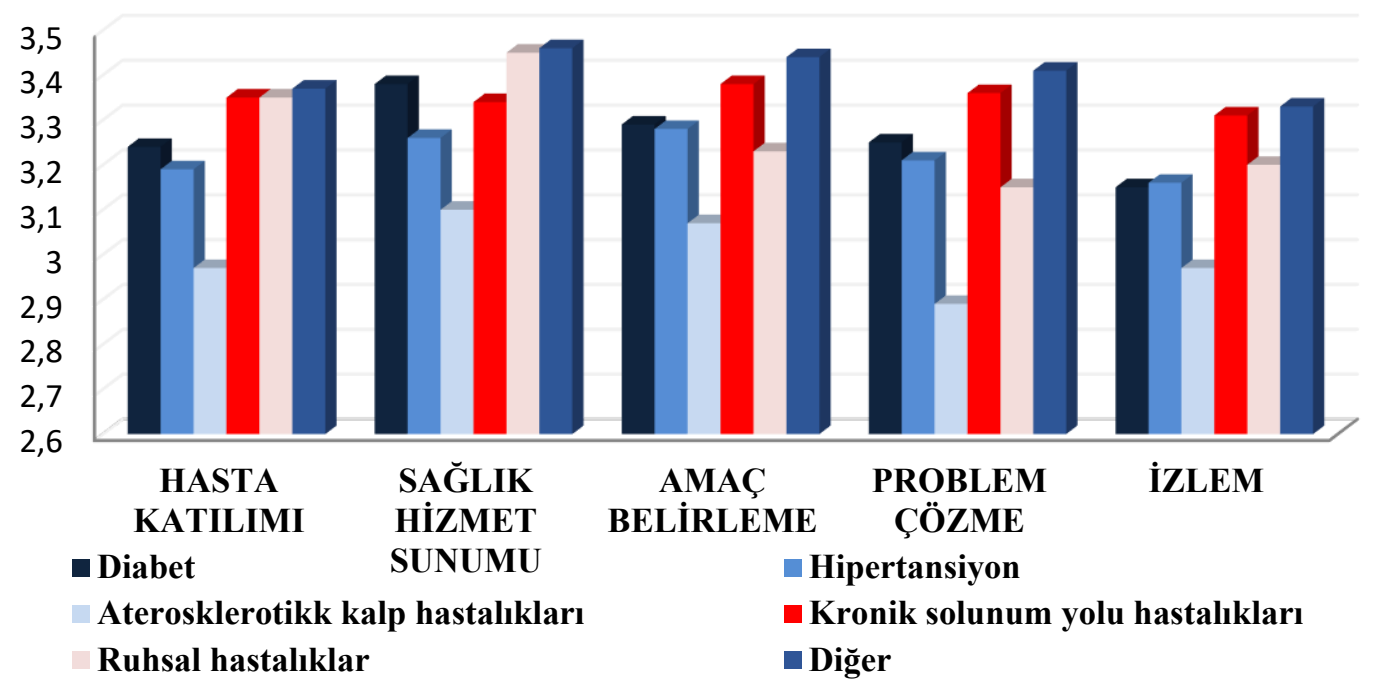

\section{Grafik 1. Kronik hastalıklara göre memnuniyet puan ortalamaları}

Çalışma kapsamındaki hastaların, sosyodemografik özelliklerinden yaş durumuna göre, kronik hastalık yönetimlerinden memnuniyet puan ortalamaları karşılaştırıldığında kronik hastalığ hastalık bakım memnuniyeti puan ortalaması daha yüksek bulunmuştur( $\mathrm{p}=0,001)$.

Cinsiyet durumuna göre bakıldığında ise, kronik hastalık bakım memnuniyetleri arasinda anlaml bir fark bulunamamıştır $(p=0,520)$. Sosyodemografik özelliklerinden eğitim düzeyi ile kronik hastalık yönetimlerinden memnuniyet puan ortalamaları karşılaştırıldığında, puan ortalamaları yönünden anlamlı ilişki bulunmamıştır( $\mathrm{p}=0,468)$.

\section{TARTIŞMA}

$\mathrm{Bu}$ çalışma, birinci basamakta sık görülen kronik hastalıklardan herhangi birine sahip olan bireylerin sağlı için yaptıkları harcamalarının aldıkları kronik hastalık bakımlarına ve ilaç uyumlarını değerlendirmesine olanak veren kişi merkezli bir araştırma olması nedeniyle önemlidir.

Tüm dünyada hem sağlık harcamaları, hem de cepten yapılan sağlık harcamalarının payı artış göstermektedir. Dünyada, cepten sağlık harcamalarının sıklığ ve yoğunluğu ile ilgili birçok çalışma yapılmasına rağmen cepten sağlık harcamalarını etkileyen faktörlerle ilgili çok fazla şey bilinmemektedir.
Çalışma kapsamındaki hastaların, kronik hastalık bakım yönetimlerinden memnuniyet puan ortalaması toplam ölçek için $3,2 \pm 0,7$ olarak hesaplanmıştır. Çalışmamızdaki hastaların kronik hastalık bakım yönetimlerinden memnuniyet puan ortalamasına bakıldığında, en düşük puanın aterosklerotik kalp hastalığı olan bireylerde en yüksek puanın da kronik solunum yolu hastalığ1 bulunanlarda olduğu görülmüştür. Çalışmamıza katılan hastaların, PACIC ölçeğine verdikleri puana göre alınan bakımın "iyi düzeyde" değerlendirdiklerini ve aldıkları bakımdan memnun olduklarını düșündürebilir. Glasgow ve arkadaşlarının, Amerika'da çeşitli kronik hastalığı olan bireylerde yaptığ çalışmada ise hastalıklara göre memnuniyet puan ortalamaları hipertansiyon ve diyabetli hastalarda en yüksek, astımlı hastalarda en düşük bulunmuştur. ${ }^{(10)}$

Rosemann ve arkadaşlarının, Almanya'da çeşitli kronik hastalığı olan bireyleri kapsayan çalışmasında, elde edilen memnuniyet puan ortalamaları diyabetli hastalarda 2,7; hipertansiyon hastalarında 2,4; astım/KOAH hastalarında 2,4 olarak bulunmuştur. ${ }^{(11)}$ Ülkemizde yapılan az sayıdaki çalışmaları incelediğimizde ise İncirkuş ve arkadaşlarının yaptığı Türkçe geçerlik güvenirliğin araştırıldığı, katılımcıların çoğunun hipertansiyon ve diyabet hastalarının oluşturduğu hastane bazlı çalışmada, ölçek ortalama puanı, 2,5 $\pm 0,9$ olarak bildirilmiştir. ${ }^{(12)}$

Çalışmamızda, kronik hastalıkların çoğunluğu hipertansiyon ve diyabet hastalarından oluşmaktaydı. Bulunan kronik hastalıklar arasında aterosklerotik kalp 
hastalığı bulunan hastaların kronik hastalık yönetimlerinden memnuniyet puan ortalamaları yönünden en düşük memnuniyet puan ortalamasına sahip olduğu saptanmıştır. $\mathrm{Bu}$ durumunda aterosklerotik kalp hastalığ bulunan bireylerin ek birçok kronik hastalıkla birlikte olması ve bu durumunda hastalığı daha zor bir duruma ve bakım memnuniyetinde azalmaya yol açabileceği düşünülmektedir.

Çalışmamızda, hastaların toplam ölçek puanları oldukça yüksek olmakla birlikte alt ölçek puan ortalamaları arasında farklı sonuçlar elde edilmiştir. $\mathrm{Bu}$ çalışma kapsamındaki hastaların alt ölçeklerden aldıkları puan ortalamaları en yüksek sağlık hizmetleri sunum planı, en düşük ise izlem olarak bulunmuştur. Bu boyuttaki yüksek puanlar hastaların hastalık ve tedavilere bağlı yaşanabilecek sıkıntıların belirlenmesi ve çözümü konusunda doktor ve hemşirelerden aldıkları destekten memnuniyetlerinin yüksek olduğunu düşündürmektedir.

Ayrica bu alt boyut doktor ya da hemşirelerin gerekli olan tedaviyi önerirken hastanın değerlerini, inançlarını ve geleneklerini dikkate almalıdır.

Hastanın tedavi planını yapması ve zor zamanlarda bile kendine bakabilmesi için yapması gerekenler konusunda yardım edilmesi ve hastalığın hayatı nasıl etkilediğinin sorulması gibi durumları içermektedir. ${ }^{(12)}$ Yapılan bazı çalışmalarda da alt ölçeklerden aldıkları en yüksek puanın problem çözme alt boyutunda, en düşük puanın ise hasta katılımı alt boyutunda olduğu görülmektedir.

$\mathrm{Bu}$ yapılan çalıșmada da, kronik hastalıkları bulunan bireylerin sağlık hizmet alımının etkilenen bireylerin Modifiye PACIC skoruna baktığımızda, sağlık hizmet alımı etkilenmeyenlere oranla daha düşük bulunduğu görülmektedir. Ama alt ölçeklere göre bazı farklılıklar bulunmuştur. "sağlık hizmet sunumu”, "amaç belirleme”, "problem çözme”, izlem' de anlamlı farklılıklar bulunmuştur. "Hasta katılımı" ise benzer oranda bulunmuştur.

$\mathrm{Bu}$ farklılıklar, hasta katılımı boyutu hastaların tedavi planında görüşlerinin alınması, tedavi ile ilgili başka seçeneklerin sunulması ve ilaçlar/etkileri ile ilgili sorunların bildirilmesinin istenmesi gibi durumlar da farklılıklar olmadığını göstermektedir. ${ }^{(13)}$ Ama diğer alt ölçeklerde 'sağlık hizmet sunumu', 'amaç belirleme', 'problem çözme', izlem' de sağlık hizmet alımı etkilenmeyenlerin daha memnun olduğunu göstermektedir.

$\begin{array}{lrr}\begin{array}{l}\text { Çalışma kapsamındaki } \\ \text { sosyodemografik özelliklerinden }\end{array} & \begin{array}{r}\text { cinsiyet } \\ \text { durumuna göre, kronik }\end{array} \\ \text { höntalıtimlerinden } \\ \text { ortalamaları memnuniyet } & \text { puan } \\ \text { karşıllaştırıldığında } & \text { puan }\end{array}$ ortalamaları yönünden anlamlı bir fark bulunmamıştır. Glasgow ve arkadaşlarının yaptığı çalışmada ise cinsiyet durumu ile kronik hastalık bakım memnuniyeti puan ortalamaları arasında bir ilişki bulunmuştur. ${ }^{(12)}$

Bizim çalışmamıza benzer olarak İncirkuş ve arkadaşlarının yaptığı çalışmada, yine Kaya ve arkadaşlarının 2013 yılında çeşitli kronik hastalığı olan bireylerde yaptığı çalışmada da cinsiyet durumuna göre, kronik hastalık puan ortalamaları karşılaştırıldığında puan ortalamaları yönünden anlamlı bir fark bulunmamıştır. ${ }^{(13,14)}$

$\begin{array}{lcrr} & \text { Çalışma } & \text { kapsamındaki } & \text { hastaların } \\ \text { yaşları } & \text { ile } & \text { ilgili kronik } & \text { hastalık } \\ \text { yönetimlerinden } & \text { memnuniyet } & \text { puan } \\ \text { ortalamaları } & \text { karşılaştırıldığında, } & \text { puan }\end{array}$ ortalamaları yönünden anlamlı ilişki saptanmış yaş ilerledikçe hastaların kronik hastalık bakım yönetiminden daha çok memnun kalmışlardır.

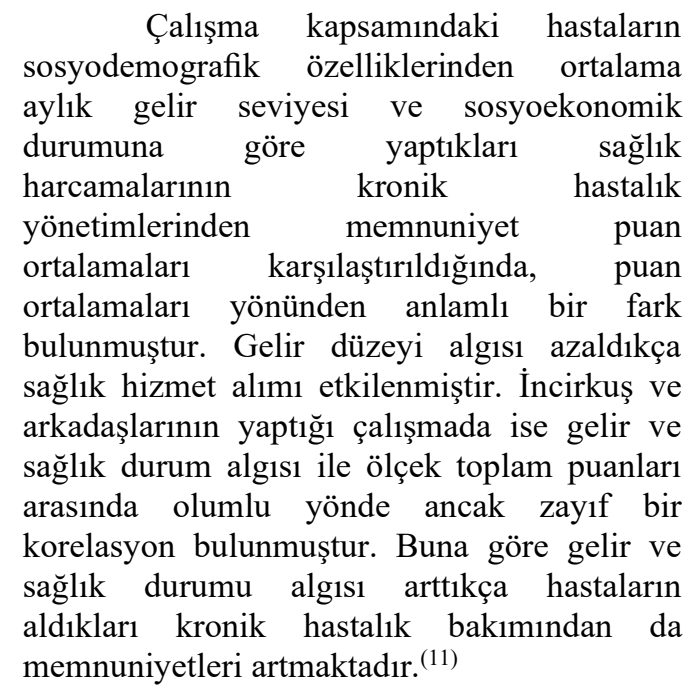

Yapılan bir çalışma da hanenin gelir dilimi ile cepten sağlık harcaması yapma durumu arasındaki ilişki incelendiğinde, 1 . gelir dilimine göre en fazla harcama durumu, 5. gelir dilimine sahip hanelerde görülmektedir. Hanenin gelir dilimi arttıkça, cepten sağlık harcaması yapma durumu da artmaktadır. Bu durum geliri yüksek olan hanelerin daha fazla sağlık hizmeti alması ve daha pahalı hizmet sunuculardan alması ile açıklanabilir. 1. gelir diliminde olanların da 
düşük gelir düzeyi, sağlık hizmeti kullanımının düşük olması (düşük okuryazarlık seviyesi ve sağlıkta farkındalığın az olması nedeniyle) ile açıklanabilir. Ulusal ve uluslararası literatürde bu sonucu destekleyen çalışmalar bulunmakla birlikte tam tersi sonuçlar elde edilen çalışmalar da mevcuttur. Örneğin, TSİHA' da gelir düzeyi yüksek olan hanelerin cepten harcamalarının da yüksek olduğu, hastalandığı zaman hiçbir şey yapmayanların düşük gelir diliminde daha fazla olduğu bulunmuştur. USH Hane halkı araştırmasına göre ise 1. gelir dilimi, 5. gelir dilimine göre daha fazla cepten harcama yapmıştır. ${ }^{(14)}$

$\mathrm{Bu}$ çalışmada, hastaların eğitim düzeyi ile kronik hastalık yönetimlerinden memnuniyet puan ortalamaları karşılaştırıldığında puan ortalamaları yönünden anlamlı ilişki saptanmamış olup, bu konuda yapılan bazı uluslararası çalışma bulgularında da eğitim düzeyinin anlamlı olarak etkilediğine dair sonuçlar elde edilmiştir.

Rosemann ve arkadaşlarının 2007 yılında, Wensing ve arkadaşlarının 2008 yılında, Jackson ve arkadaşlarının 2008 yılında, Taggart ve arkadaşlarının 2009 yılındaki çalışmasında da eğitim seviyesi yüksek olan hastaların toplam ölçek puanları daha yüksek bulunmuş ve bu durum eğitimli insanların gerekli bakımı alma, uyum ve öz yönetimde daha iyi olmasıyla açıklanmıştır. (1114)

Bununla beraber Glaskow ve arkadaşlarının 2005 yılında birinci basamak sağlık ortamlarında kronik hastalığ kişide yürüttükleri çalışmada eğitim düzeyi ile PACIC skoru arasında bir farklılık bulunmadığ 1 bildirilmiştir. ${ }^{(13)}$ Benzer şekilde osteoartrit ve hassas barsak sendromu olan hastaların PACIC ölçeği ile değerlendirildiği çalışmalarda da hastaların eğitim düzeyi grupları arasında PACIC ortalama skoru açısından anlamlı bir fark bulunmadığ bildirilmiştir. ${ }^{(15,16)}$ Farklı olarak KOAH veya kardiyovasküler hastalığı olan kişilerde yapılan çalışmada eğitim düzeyinin artması ile PACIC puanlarının arttığı bildirilmiştir. ${ }^{(16,17)}$

Kronik hastalığı bulunan bireylerin sağlık harcamalarının, sağlık hizmet alımını etkilediğini söyleyen grupla, etkilemediğini söyleyenlerin toplam Modifiye PACIC skorları karşılaştırıldığında iki grup arasındaki PACIC skorları arasında anlamlı bir fark bulunmuştur. Sağlık hizmet alımı etkilenmeyen hastalarda kronik hastalık bakım memnuniyetinin daha iyi düzeyde olduğu görülmüştür.
$\mathrm{Bu}$ çalışma da, kronik hastalık sayısı ile yapılan harcamaların sağlık hizmet alımını etkileyip etkilemediği karşılaştırıldığında kronik hastalık sayısının sağlık hizmet alımını etkilemediği bulunmuştur. Kronik hastalık bulunan bu bireylerde ikiden az kronik hastalığı bulunan bireylerle, ikiden fazla kronik hastalığı bulunan bireyler karşılaştırıldığında kronik hastalık bakım memnuniyet ortalama toplam Modifiye PACIC skorunda anlamlı bir fark bulunamamıştır. Yapılan başka çalışmada ise hastalık olmaması durumu referans alındığında, son 2 ay içinde tanı konmuş akut-kronik hastalık olması durumunda cepten sağlık harcaması yapma durumu 65,4 kat daha fazla olmaktadır. Son 2 ay hariç tanı konmuş kronik hastalık olması durumunda bu oran 7,6 kat, hem son 2 ay içinde tanı konmuş akut-kronik hastalık hem de son 2 ay hariç tanı konmuş kronik hastalık olması durumunda ise 67,9 kat daha fazla cepten sağlık harcaması yapılmak durumunda kalınmaktadır. ${ }^{(18)}$

Modifiye PACIC alt ölçeklerinden ise "Problem Çözme", "İzlem", "Amaç Belirleme" de anlamlı bir fark bulunur iken "Hasta katılımı", "Sağlık Hizmet Sunumu", arasında ise anlamlı bir fark bulunamıştır.

$\mathrm{Bu}$ durumda kronik hastalığ bireylerin kendi bakımına katılımından memnuniyet oranının düşük olduğu, sağlık hizmet sunumundan tedavisini belirlemedeki rolünden memnuniyetinin diğer ölçeklere göre düşük olduğu bulunmuştur.

Hizmette kapsayıcılık veya bütüncül yaklaşım ilkesi, birinci basamağın toplumda sık görülen tüm sağlık sorunlarını tanımlayabilecek ve müdahale edebilecek düzeyde olmasıdır. Birinci basamaktan sevk oranının yüksek olması, kapsayıcılığın yetersiz kaldığını göstermektedir ${ }^{19)}$. Birinci basamakta kronik hastalı takibinde hem bazı tetkiklerin eksikliği hem uzman yetersizliğinden kaynaklı olarak kronik hastalığı olan hastalar da sevk oranı fazlalaştırmış olabilir. Birinci basamakta takip oranı azaldığı için hastalar takiplerine diğer basamaklarda devam etmektedir. $\mathrm{Bu}$ durumda hastalarda birinci basamakta takibin daha az gibi bir görüş oluşturmuş oalbilecği düşünülmektedir.

Birinci basamak sistemi güçlü olan ülkelerde gelişmemiş olanlara göre sevk oranlarının gözle görülür derecede az olduğu yapılan araştırmalarda gösterilmiştir ${ }^{(20)}$. 
Ülkemizde birinci basamağın önümüzdeki yıllarda daha da güçlenmesi adına, bazı problemlerin saptanması ve bunlara yönelik çözümler üretilmesi gerekmektedir. Öncelikli olarak yapılması gereken, ufak değişikler ile aile hekimliğini daha cazip hale getirmek olmalıdır. Multidisipliner işbirliği bağlamında ulusal "kronik hastalık yönetimi" programları oluşturularak sağlık hizmet sunumunda diyabet, obezite, hipertansiyon, koroner arter hastalığı, kronik obstrüktif akciğer hastalığı gibi bulaşıcı olmayan hastalıkların takibinde birinci, ikinci, üçüncü basamakta entegre sağlık hizmet sunumu sağlanması, gerekli mevzuat düzenlenmelerinin yapılması gerekmektedir $^{(21)}$

Ortak bakım planı çerçevesinde elektronik ağlar; aile hekimleri, hastane, yaşlı bakım evleri, sosyal güvenlik kurumları arasında güçlendirilmelidir. Taburcu olan hastaların epikrizlerinin elektronik ortamda aile hekimlerince görülebilirliğinin sağlanması ve taburcu olan hastaların bağlı olduğu aile hekimlerinin hastanın opere olduğu veya yatarak tedavi gördüğü klinikle elektronik ortamda konsülte edebilmeleri, hem hasta hem de hekim açısından kolaylık sağlayacaktır ${ }^{(22)}$

Grup aile sağlığ özendirilmesi ve çoklu aile hekimlerinin çalıştıkları yerlerde psikiyatri, dâhiliye veya çocuk uzmanlarının da çalışabilmesinin önünün açılması, hem aile sağlığ merkezlerindeki doktor açı̆̆ını kapatacak hem de doktor başına düşen hasta sayısının daha azami miktarlarda olmasinı sağlayacaktır ${ }^{(21)}$

Sağlık harcamalarındaki artışın nedenleri arasında sayılabilecek faktörler arasında tıbbi teknoloji de yer almaktadır. Tıbbi alanda görülen gelişmeler ve artan sağlık bilinci, sağlık alanında yapılan harcamaları değiştirmiştir Sağlık hizmeti sunanlar kendilerini, tıptaki en son yenilikleri kullanma konusunda hem profesyonel (mesleki açıdan) hem de klinik (hasta memnuniyeti) olarak baskı altında hissetmektedirler. Biz hekimler hasta için maliyeti en düşük, en etkin tedaviyi seçmeliyiz. ${ }^{(10)}$

\section{SONUC}

Çalışmamıza katılan hastaların, Modifiye PACIC ölçeğine ortalama $3,2 \pm 0,7$ puan vermesi alınan bakımın "iyi düzeyde" değerlendirdiklerini göstermiştir. Bununla beraber hastaların alt ölçeklerden aldıkları puan ortalamaları en yüksek; sağlık hizmetleri sunum planı, en düşük ise izlem olarak bulunmuştur. $\mathrm{Bu}$ durum hastaların hastalık ve tedavilere bağlı yaşanabilecek sıkıntıların belirlenmesi ve çözümü konusunda doktor ve hemşirelerden aldıkları destekten memnuniyetlerinin yüksek olduğunu düşündürmektedir. Fakat kronik hastalığ1 bulunan bireylerin periyodik izlemde memnuniyetin düşük olmasından dolayı takiplere daha çok önem verilmesi ve bu eksikliklerin nedeninin belirlenmesi için ek çalışmalar yapılması önerilmektedir.

Ayrıca cepten yapılan sağlık harcamalarının, hizmet alımını etkilemediğini belirten hastaların Modifiye PACIC alt ölçek skorları genel olarak daha yüksek bulunmuştur. Ayrıca hastaların gelir düzeyinin kronik hastalık bakımlarını etkilediği sonucuna ulaşılmıştır. Bu durumda aile hekimleri, bireylere gerekli tedavi verilirken; gelir düzeyi, eğitim durumu, yaşı, sosyal güvencesi, beklentileri, kronik hastalık özellikleri, kişinin fiziksel, kültürel değerler gibi özellikleri dikkate alınarak tedavi yaklaşımı göstermelidir. Kronik hastalığı bulunan bireylere yapılacak müdahalelerde, istenecek tetkiklerin, reçete edilecek ilaçların maliyeti düşük, yaşam kalitesi yüksek olanların bilinmesi için de çalışmalar yapılmalıdır.

Cepten sağlık harcamasının hangi koşullarda yapıldığ kişileri bu harcamalardan koruyacağ $\breve{1}_{1}$ ve kişilerin cepten sağlık harcaması yapmalarını sağlayan faktörler hakkında çok az şey bilinmektedir. Ancak bilinen en önemli şey, hanelerin sosyoekonomik özelliklerinin cepten sağlık harcaması yapmaları ile yakından ilişkili olduğudur. Bu özelliklerin tespit edilmesi, eşit sağlı hizmetinden yararlanmanın sağlanmasında en uygun müdahalenin adapte edilmesinde yardımcı olacaktır.

\section{KAYNAKLAR}

1. Waters H.R. G.F Anderson, J. "Measuring Financial Protection in Health in the United States", Health Policy,2004; 69:339-349.

2. $\mathrm{Xu} \mathrm{K}$,, D Evans, K. Kawabata, R. Zeramdini, J. Klavus and C. Murray "Household Catastrophic Health Expenditure A Multicountry Analysis", Lancet,2003: 362, 111-17.

3. Ruger J.P. and Kim H. Out-of-Pocket Healthcare Spending by the Poor and 
Chronically Ill in the Republic of Korea. American Journal of Public Health 2007; 97(5): 804-811.

4. Chu, T., T. Liu T., C. Chen, Y. Tsai, W. Chiu "Household out-of- Pocket Medical Expenditures and National Health Insurance in Taiwan: Income and Regional Inequality", BMC Health Services Research,2005;5: 60-67.

5. Austvoll-Dahlgren et al. Sağlık Bakanlığı, RSHMB, Hıfzıssıhha Mektebi Müdürlüğü Türkiye Ulusal Hanehalkı Sağlık Harcamaları Araştırması Hacettepe Sağlık İdaresi Dergisi ,2005;09:10-2

6. İncirkuş K, Nahcivan NÖ. Kronik Hastalık Bakımını Değerlendirme ÖlçeğiHasta Formu'nun Türkçe Versiyonunun Geçerlik ve Güvenirliği. DEUHYO ED 2011;4(1):102-109.

7. Ensor T. and San P.B. Access and Payment for Health Care. The Poor of Northern Vietnam. International Journal of Health Planning and Management 1996: 11(1): 69-83

8. Zich, C.D., J.X. Fan and K. Chang "Impending Widowhood and Health Care Spending”, Social Science Research,2004: 33, 538-555.

9. Liu G.G. and Zhao Z. Et all Urban Employee Health Insurance Reform and the Impact on Out-of-pocket Payment in China. International Journal of Health Planning and Management 2009;21(3): 211-228.

10. Wensing, M., Lieshoud, J. V. Jung, H. P., Hermsen, J.\& Rosemann, T. The patients assessment chronic illness care (PACIC) questionnaire in the Netherlands: A validation study in rural general practice. British Medical Journal, 2008;8:182- 188

11. Rosemann, T., Laux, M. D., Droesemeyer, S., Gensichen, J., \& Szecsenyi, J. Evaluation of a culturally adapted German version of the Patient Assessment of Chronic Illness Care (PACIC) questionnaire in a sample of osteoarthritis patients. Journal of Evaluation in Clinical Practice, 2007;13, 806-813.

12. Glasgow, R.E., Wagner, E.H., Schaefer, J., Mahoney, L.D., Reid, R.J. ve Greene, S.M. Development and Validation of the Patient Assessment of Chronic Illness Care (PACIC). Med Care,2005; 43(5), 436-444.
13. Üstünova E., Nahcivan N., Kronik Obstrüktif Akciğer Hastalığı Olan Bireylerin Kronik Hastalık Yönetimine İlişkin Değerlendirmeleri ve İlişkili Faktörler. F.N. Hem. Dergisi, 2015; 23;1: 11-22.

14. Kaya Apaydın Ç, Akturan S, Ģek M, et al. Kronik hastalık bakımının hasta perspektifinden değerlendirilmesi. Turkish Family Physician 2013;4(3):1-9.

15. Cramm JM, Nieboer AP et all. Factorial validation of the patient assessment of chronic illness care (PACIC) and PACIC short version (PACIC-S) among cardiovascular disease patients in the Netherlands. Healthand Quality of Life Outcomes 2012;10:104-111.

16. Randell RL, Long MD, Martin CF, Sandler RS, Chen W, Anton K et all.Patient Perception of Chronic Illness Care in a Large Inflammatory Bowel Disease Cohort. Inflamm Bowel Dis 2013;19:1428-1433.

17. Rosemann T, Laux G, Droesemeyer S, Gensichen J, Szecsenyi J. Evaluation of a culturally adapted German version of the Patient Assessment of Chronic Illness Care (PACIC 5A) questionnaire in a sample of osteoarthritis patients. J Eval Clin Pract 2007; 13:806-813.

18. Başara Bora B, Şahin İ, Türkiye'de Cepten Yapılan Sağlık Harcamalarını Etkileyen Etmenler H.Ü. İktisadi ve İdari Bilimler Fakültesi Dergisi, 2008; Cilt 26, Say1 2, 319-340

19. Macinko J, Starfield B, Shi L. The Contribution of Primary Care Systems to Health Outcomes within Organization for Economic Cooperation and Development (OECD) Countries, Health Services Research 2003; 38(3):831-865.

20. Starfield B. Balancing Health Needs, Services and Technology. New York: Oxford University Press; 1998: 99-147.

21. Başer D.ve arkadaşları Etkin Sağlık Sistemleri İçin Güçlü Birinci Basamak Ankara Med J, Cilt 15, Say1 1, 2015:3031.

22. Allen J, Gay B, Crebolder $\mathrm{H}$ et al. The European Definition of General Practice/Family Medicine. WONCA EUROPE 2011 Edition; 2002 :8-12. 